\title{
The effect of an educational intervention on awareness of various aspects of pulmonary tuberculosis in patients with the disease
}

Kalthoum Yousif, ${ }^{1}$ Mabrouka EI Maki, ${ }^{2}$ Rosa Khalil Babikir ${ }^{1,3}$ and Hasan Abuaisha ${ }^{4}$

${ }^{1}$ Faculty of Nursing Sciences, National Ribat University, Burrie, Sudan (Correspondence to: Kalthoum Yousif: kalthoumyousif@gmail.com). ${ }^{2}$ Kamleen Ahlia College, Al-Kamleen, Jazeera State, Sudan. ${ }^{3}$ Faculty of Applied Medical Sciences, Al-Baha University, Al-Baha City, Saudia Arabia ${ }^{4}$ Department of Medicine, Al-Mughtaribeen University, Gabra, Sudan.

\begin{abstract}
Background: Tuberculosis (TB) is a major health problem worldwide. Raising awareness of various aspects of the disease among patients who have TB is important to help in control and prevention.

Aims: This was a quasi-experimental study, pre- and post-test, designed to evaluate the effect of an educational intervention on awareness among patients with pulmonary TB.

Methods: A structured questionnaire covering various facts about pulmonary TB was used in the pre-intervention phase for 150 TB patients who were being followed-up in a major hospital in Sudan $(r=0.80)$. The same questionnaire was reused after the patients underwent an educational awareness programme.

Results: There were more males (74\%) than females. Mean age was 36.5 years. Most patients (86.6\%) had some education, however, their knowledge about aspects of TB was generally poor prior to the intervention. This included the nature of the causative organism, modes of transmission and measures needed for the control and prevention. Post-intervention, there was significant improvement in all aspects of knowledge tested $(P<0.007)$.

Conclusion: Although the diagnosis of TB in the participants was confirmed and they were on regular clinical follow-up, their knowledge about various aspects of TB was poor prior to the educational intervention. There is a need for more effort towards raising awareness among patients with TB about their disease while on treatment. This is important to help control and prevent the disease.

Key words: pulmonary tuberculosis, awareness, patient education

Citation: Yousif K; EI Maki M; Babikir R; Abuaisha H. The effect of an educational intervention on awareness of various aspects of pulmonary tuberculosis in patients with the disease. East Mediterr Health J. 2021;27(3):287-292. https://doi.org/10.26719/emhj.20.102

Received: 17/04/19; accepted: 01/03/20

Copyright (C) World Health Organization (WHO) 2021. Open Access. Some rights reserved. This work is available under the CC BY-NC-SA 3.o IGO license (https://creativecommons.org/licenses/by-nc-sa/3.o/igo).
\end{abstract}

\section{Introduction}

Tuberculosis (TB) is a chronic infectious disease caused by Mycobacterium tuberculosis (1). It is the world's leading cause of death due to infectious disease (2) and was declared a global public health emergency in 1993 by the World Health Organization (WHO) (3). It has been reported that $64 \%$ of an estimated 10 million $\mathrm{TB}$ cases are detected and treated each year (2). Identification of risk factors is crucial for policy-makers to put in place appropriate strategies to prevent the disease and reduce the global burden of TB (3). The disease can be avoided and cured completely, depending on the level of health awareness and knowledge of the community through prevention and control (4). All WHO Member States have adopted the "End TB Strategy", which covers the period 2016-2035 (5).

The social stigma of TB is high in all categories of the community, irrespective of education level (6). Control is a high priority and has become an international objective with the increasing number of cases throughout the world, including the developed countries (6). Sudan has high prevalence of TB: incidence was 114 cases per 100000 population in 2012 (2), reported to have increased to 117 per 100000 population in 2016 , probably due to poverty and low health expenditure (6.2\% of GDP) (7). The country accounts for $15 \%$ of the TB burden in the WHO Region for the Eastern Mediterranean (8). It was recently observed that $26.6 \%$ of patients with $\mathrm{TB}$ in the Region had extra-pulmonary TB $(9,10)$.

Sudan is an extremely turbulent country that has seen years of civil conflict, including the North-South and Darfur crises (11). Conflicts impact health infrastructure and human resources, which can hinder disease prevention and control measures. This escalates the burden of communicable diseases such as tuberculosis (11). In addition, conflicts lead to the displacement of populations and impair access to health care. This can increase TB transmission, worsen patient outcomes and lead to increasing rates of drug resistance (12). Notified TB cases have remained relatively constant in Sudan over the past decade, within the range 19817 to 22097 (7). However, the prevalence of multi-drug resistant TB, as reported by Sudan's national TB programme in 2012, was $19.0 \%$ in re-treatment cases and $1.8 \%$ in new cases (7).

A national TB programme has been developed and implemented since 1992 in accordance with the 
recommendations of the International Union against $\mathrm{TB}$ and Lung Disease (13).

This study was designed to evaluate the awareness of patients who have pulmonary TB before and after an educational intervention. The emphases were on the importance of ways to prevent the spread of the disease and compliance to treatment schedules.

\section{Methods}

\section{Study design}

The study was a quasi-experimental pre- and post-test educational intervention carried out on patients with proven pulmonary $\mathrm{TB}$ who were attending the chest clinic in Omdurman Military Medical Corps Hospital for follow-up during the period April-July 2018. The chest clinic is held twice a week: one morning and one afternoon session.

Inclusion criteria in the study were: adult patients (age above 18 years); diagnosis of pulmonary TB documented in the medical records; patients on follow-up for at least 2 months; patients attended the follow-up regularly; and patients noted to be compliant to treatment by their treating team.

Exclusion criteria were: incomplete medical records; and not willing to participate in the study.

The research fellow (MEM) attended both clinics every week with prior permission of the consultant physicians in charge. On average there were about 6 patients with proven pulmonary TB per clinic. Over the study period, our researcher (MEM) approached 190 patients who fulfilled the inclusion criteria while waiting to be seen or soon after being seen by the treating team (convenience sampling method). She explained the research objectives to each patient and recorded the required information from 150 patients who accepted to participate in the study. Participants in the study were requested to attend educational sessions of at least 2 hours each, in groups according to their convenience. The educational sessions were arranged with the collaboration of the treating team, and each group answered the same questionnaire after completion of the session.

A structured questionnaire was designed by the authors, revised, amended and finally approved by an expert committee consisting of 2 consultants from the Department of Communicable Diseases, Federal Ministry of Health, and 2 consultants from the Department of Community Medicine, Faculty of Medicine, the National Ribat University. The questionnaire was used in faceto face-interviews with the participants in the study. It included 6 variables for sociodemographic data and 34 items covering basic knowledge about TB: causes, mode of transmission, symptoms, treatment, control and prevention. The score for the knowledge variables was recorded by interval scale with "Yes" or "No" answers for each variable question. A score of " 1 " was awarded for each correct answer. The total score was adjusted to be out of 100 .
The content validity of the questionnaire was evaluated and approved by the panel of experts detailed above. Instrument validity and reliability were tested in a pilot study on 15 patients who answered the questionnaire before and after the educational intervention. The pilot study patients were excluded from the study sample. The Pearson correlation coefficient $(r)$ was 0.80 . A teaching programme comprising lectures, handouts, leaflets and handbooks containing the instructions for the control and prevention of the spread of the disease were distributed to the participants. The data collection time between the pre- and post-test was 4 months.

The paired samples t-test was used to measure the statistical difference between the 2 means; $95 \%$ confidence interval (CI) was used where appropriate. Statistical significance was taken at level $P \leq 0.05$.

\section{Ethical considerations}

Permission was obtained from the Research Committee on Human Subjects in the National Ribat University and from the manager and director of the TB Management Unit in the Military Hospital. All participants in the study were informed about the aim of the study and they signed a written informed consent form. It was explained that the data would be kept confidential. Participants had the right to withdraw from the study any time they wished.

\section{Results}

One hundred and fifty out of 190 patients approached agreed to take part in the study (response rate $79 \%$ ). Mean age was 36.5 (range 16-63) years. There were 111 males (74\%) and 39 females $(26 \%)$.

The majority of the participants $(86.6 \%)$ had basic education or higher: $49.3 \%$ having secondary school education and only $1.3 \%$ having higher education. Just over $13 \%$ were illiterate.

The participants were tested on their knowledge of various aspects of TB. The 4 fields covered in the questionnaire were: causative agent, mode of transmission, symptoms, and control and prevention. There was an improvement in the scores for all the variables after the educational intervention and the differences were all statistically significant. Although more than $86 \%$ of the patients were educated (about 50\% secondary school or higher) yet their knowledge about the nature of tuberculosis as an infectious disease was very low and improved significantly after the educational intervention (Table 1).

Correct information about mode of transmission of TB was very deficient prior to the educational intervention (Table 2). The knowledge that TB is transmitted by contaminated air droplets showed a high statistically significant improvement $(P<0.001)$ after the educational intervention.

Knowledge about common symptoms in pulmonary TB was alarmingly low among patients prior to the educational programme. Coughing blood was not recognized as an important symptom by the majority 
Table 1 Knowledge in regard to agents causing tuberculosis (TB) (correct answer scores) prior to and after the intervention $(n=150$, degrees of freedom $=148)$

\begin{tabular}{|c|c|c|c|c|c|c|c|c|}
\hline \multirow[t]{3}{*}{ Knowledge variable } & \multicolumn{4}{|c|}{ Score } & \multicolumn{2}{|c|}{$95 \% \mathrm{CI}$} & \multirow[t]{3}{*}{$\mathbf{t}$} & \multirow[t]{3}{*}{$\boldsymbol{P}$} \\
\hline & \multicolumn{2}{|c|}{ Pre-test } & \multicolumn{2}{|c|}{ Post-test } & \multirow[b]{2}{*}{ Lower } & \multirow[b]{2}{*}{ Upper } & & \\
\hline & Mean & SD & Mean & SD & & & & \\
\hline $\mathrm{TB}$ is an infectious disease & 0.59 & 0.49 & 0.95 & 0.23 & -0.44 & -0.27 & -8.0 & $<0.003$ \\
\hline $\mathrm{TB}$ is a bacterial infection & 0.55 & 0.50 & 0.96 & 0.20 & -0.50 & & -9.4 & $<0.001$ \\
\hline $\mathrm{TB}$ is a viral infection & 0.53 & 0.50 & 0.93 & 0.25 & -0.50 & -0.32 & -8.9 & $<0.006$ \\
\hline TB is a parasitic infection & 0.53 & 0.50 & 0.93 & 0.25 & -0.50 & -0.32 & -8.9 & $<0.006$ \\
\hline
\end{tabular}

CI = confidence interval; $S D=$ standard deviation.

of patients until they were educated about this (Table 3). Although our participants were coming regularly for medical follow-up, more than a third of them were not aware of the importance of strict compliance to the treatment regimen (Table 4).

Prior to our educational intervention, only $55 \%$ of the respondents knew that TB was a bacterial infection. This rose to $96 \%$ post-intervention. Similarly, knowledge that the major source of infection was via contaminated droplets in the air increased from $60 \%$ of participants to 93\% after the intervention.

\section{Discussion}

In this study, the majority of patients (74\%) were males. This is consistent with a WHO study from Eastern Sudan which reported that pulmonary TB was commoner among males in the general population (14).The mean age of our patients was 36.5 years, i.e. the young productive age, a finding that supports the view that this disease has a high impact on productivity and the economy $(3,5)$.

Although about $50 \%$ of our sample had reasonably good education, their knowledge of various aspects of TB prior to the educational intervention was generally poor. Awareness is a very important parameter to be assessed in order to provide baseline data to assist decision-makers in the planning and delivery of an effective control programme (14).

It is rewarding that after our educational intervention the participants attained a high (statistically significant) knowledge score (around 90\%) in all variables. A study done in Egypt in 2012 showed similar findings, i.e. significant improvement following an educational intervention programme (15).

Prior to our educational intervention, only $55 \%$ of the respondents knew that $\mathrm{TB}$ was a bacterial infection; this almost doubled after the intervention. A 2006 WHO report stated that there was lack of awareness of even the occurrence of TB in Khartoum State in (16). Similarly, only $60 \%$ of our respondents knew that the major source of infection was contaminated droplets, improving to $93 \%$ after the intervention, over 50\% improvement. It is now known that the major source of TB is droplet infection, and the droplet nuclei generated by sputum-positive patients with pulmonary TB particles must be fresh enough to carry a viable organism. Other research has established that various social determinants compound the issue: these include gender issues, unemployment, illiteracy, poor nutrition, indoor air pollution, political instability and lack of access to proper sanitation and health education $(17,18)$.

Knowledge of symptoms related to pulmonary TB was disturbingly poor in our study sample. Only about one third of the respondents gave the correct answers prior to the intervention. This improved significantly post-intervention. Similar findings were reported by Lewis et al. in 2004 (19).

Again knowledge about measures needed for control and prevention improved significantly post intervention. Gaps in the knowledge, such as mode of transmission, treatment measures and prevention, can lead to diagnostic and treatment delays among many of those living with TB. Delays in treatment occur for several reasons, e.g. lack of knowledge, lack of awareness

Table 2 Knowledge in regard to mode of transmission of tuberculosis (TB) (correct answer scores) prior to and after the intervention $(n=150$, degrees of freedom $=148)$

\begin{tabular}{|c|c|c|c|c|c|c|c|c|}
\hline \multirow[t]{3}{*}{ Knowledge variable } & \multicolumn{4}{|c|}{ Score } & \multicolumn{2}{|c|}{$95 \% \mathrm{CI}$} & \multirow[t]{3}{*}{$t$} & \multirow[t]{3}{*}{$\mathbf{P}$} \\
\hline & \multicolumn{2}{|c|}{ Pre-test } & \multicolumn{2}{|c|}{ Post-test } & \multirow[b]{2}{*}{ Lower } & \multirow[b]{2}{*}{ Upper } & & \\
\hline & Mean & SD & Mean & SD & & & & \\
\hline $\begin{array}{l}\text { TB is transmitted through contaminated air } \\
\text { droplet }\end{array}$ & 0.60 & 0.49 & 0.93 & 0.25 & -0.42 & -0.24 & -7.4 & $<0.001$ \\
\hline $\mathrm{TB}$ is transmitted through shaking hands & 0.57 & 0.50 & 0.93 & 0.25 & -0.45 & -0.27 & -7.9 & $<0.007$ \\
\hline $\mathrm{TB}$ is transmitted through sharing dishes & 0.55 & 0.50 & 0.91 & 0.28 & -0.45 & -0.27 & -7.7 & $<0.004$ \\
\hline
\end{tabular}

CI = confidence interval; $S D=$ standard deviation. 
Table 3 Knowledge in regard to symptoms of tuberculosis (correct answer scores) prior to and after intervention $(n=150$, degrees of freedom 148)

\begin{tabular}{|c|c|c|c|c|c|c|c|c|}
\hline \multirow[t]{3}{*}{ Knowledge variable } & \multicolumn{4}{|c|}{ Score } & \multicolumn{2}{|c|}{$95 \%$ CI } & \multirow[t]{3}{*}{$t$} & \multirow[t]{3}{*}{$\mathbf{P}$} \\
\hline & \multicolumn{2}{|c|}{ Pre } & \multicolumn{2}{|c|}{ Post } & & & & \\
\hline & Mean & SD & Mean & SD & Lower & Upper & & \\
\hline Coughing for 3 weeks or more & 0.65 & 0.48 & 0.99 & 0.12 & -0.42 & -0.26 & -8.4 & $<0.001$ \\
\hline Coughing up blood & 0.33 & 0.47 & 0.93 & 0.25 & -0.69 & -0.51 & -13.7 & $<0.001$ \\
\hline $\begin{array}{l}\text { Chest pain worse with } \\
\text { breathing }\end{array}$ & 0.35 & 0.48 & 0.84 & 0.37 & -0.59 & -0.40 & -10.0 & $<0.001$ \\
\hline Weight loss & 0.32 & 0.47 & 0.85 & 0.35 & -0.63 & -0.44 & -11.1 & $<0.003$ \\
\hline Fatigue & 0.33 & 0.47 & 0.82 & 0.39 & -0.58 & -0.39 & -9.8 & $<0.009$ \\
\hline Night fever & 0.37 & 0.49 & 0.89 & 0.32 & -0.61 & -0.42 & -10.8 & $<0.003$ \\
\hline Night sweats & 0.39 & 0.49 & 0.83 & 0.38 & -0.53 & -0.33 & -8.6 & $<0.006$ \\
\hline Chills & 0.43 & 0.50 & 0.85 & 0.35 & -0.52 & -0.33 & -8.6 & $<0.005$ \\
\hline
\end{tabular}

CI = confidence interval; $S D=$ standard deviation.

of the significance of symptoms, negative social attitudes and combinations of these 3 factors (20-23). This can be explained by the fact that pulmonary tuberculosis is a disease associated with poverty and low socioeconomic level (23). Research has shown that a poor standard of living and overcrowding are related, and both contribute to the prevalence of the disease (1). Other factors that have resulted in increasing the trend of TB in Africa are HIV infection, malnutrition, crowded living conditions, lack of access to free or affordable health care services and dependence on traditional healers (24). The WHO is working to reduce the burden of TB and halve the number and prevalence of TB deaths by 2015 through its Stop TB strategy and supporting the Global Plan to Stop TB (25).

Tuberculosis is preventable using effective vaccination. However, the Bacillus Calmette-Guérin (BCG) vaccine has been the only successful TB vaccine so far (26). The BCG vaccine is usually given by intramuscular injection to babies and children from birth up to 16 years; it is also sometimes given to adults up to 35 years (27). The adults are often given a tuberculin skin test (TST) before vaccination, but the vaccine does not work well in adults due to a number of factors, including the method used, route of administration, environment and characteristics of the population (27).

\section{Conclusion}

Although the diagnosis of TB in the participants in this study was proven and they were on regular clinical follow-up, their knowledge about various aspects of their disease was poor prior to the educational intervention. This reflects the need for more efforts towards raising awareness among patients with TB while on treatment. This is important to help in the control and prevention of the disease. Our educational intervention resulted in significant improvement in all the aspects of knowledge tested in our participants. This emphasizes the educational role of the health care providers in the management, control and prevention of TB.

Table 4 Knowledge in regard to control, prevention and compliance with treatment of tuberculosis (correct answer scores) prior to and after intervention $(n=150$, degrees of freedom 148$)$

\begin{tabular}{|c|c|c|c|c|c|c|c|c|}
\hline \multirow[t]{3}{*}{ Knowledge variable } & \multicolumn{4}{|c|}{ Score } & \multicolumn{2}{|c|}{$95 \% \mathrm{CI}$} & \multirow[t]{3}{*}{$t$} & \multirow[t]{3}{*}{$\mathbf{P}$} \\
\hline & \multicolumn{2}{|c|}{ Pre } & \multicolumn{2}{|c|}{ Post } & \multirow[b]{2}{*}{ Lower } & \multirow[b]{2}{*}{ Upper } & & \\
\hline & Mean & SD & Mean & SD & & & & \\
\hline Take varied and adequate food & 0.47 & 0.50 & 0.87 & 0.33 & -0.50 & -0.31 & -8.3 & $<0.004$ \\
\hline Avoid crowding & 0.45 & 0.50 & 0.87 & 0.33 & -0.52 & -0.32 & -8.6 & $<0.006$ \\
\hline Cover mouth and nose on coughing & 0.52 & 0.50 & 0.91 & 0.29 & -0.48 & -0.29 & -8.2 & $<0.009$ \\
\hline Avoid sharing dishes & 0.51 & 0.50 & 0.87 & 0.33 & -0.46 & -0.26 & -7.3 & $<0.002$ \\
\hline Open windows for fresh air & 0.50 & 0.50 & 0.87 & 0.34 & -0.46 & -0.27 & -7.4 & $<0.001$ \\
\hline Complete your treatment (compliance) & 0.39 & 0.49 & 0.91 & 0.29 & -0.60 & -0.42 & -11.0 & $<0.006$ \\
\hline
\end{tabular}

CI = confidence interval; $S D=$ standard deviation. 


\section{Acknowledgement}

We thank the administration and physicians in charge of the chest clinic in Omdurman Military Medical Corps Hospital for allowing us to conduct this study and giving us free access to see and interview the patients over the study period.

Funding: None.

Competing interests: None declared.

\section{Effet d'une intervention éducative sur la sensibilisation aux divers aspects de la tuberculose pulmonaire chez les patients atteints par cette maladie}

\section{Résumé}

Contexte: La tuberculose constitue un problème de santé majeur dans le monde entier. Il est important de sensibiliser les patients tuberculeux à divers aspects de la maladie afin de contribuer à la lutte et à la prévention.

Objectifs : Il s'agissait d'une étude quasi expérimentale, préalable et postérieure à l'intervention, conçue pour évaluer l'effet d'une intervention éducative sur la sensibilisation des patients atteints de tuberculose pulmonaire.

Méthodes : Un questionnaire structuré couvrant divers faits sur la tuberculose pulmonaire a été utilisé dans la phase pré-intervention auprès de 150 patients tuberculeux qui étaient suivis dans un grand hôpital au Soudan ( $r=0,80)$. Le même questionnaire a été réutilisé après que les patients ont suivi un programme de sensibilisation.

Résultats : Il y avait plus d'hommes (74 \%) que de femmes. L'âge moyen était de 36,5 ans. La plupart des patients (86,6 \%) avaient un certain niveau d'éducation, mais leurs connaissances sur les aspects de la tuberculose étaient généralement insuffisantes avant l'intervention. Ceci concernait notamment la nature de l'agent causal, ses modes de transmission et les mesures nécessaires pour lutter contre la maladie et la prévenir. Suite à l'intervention, il y a eu une amélioration significative dans tous les aspects des connaissances testées $(p<0,007)$.

Conclusion : Bien que le diagnostic de tuberculose des participants ait été confirmé et que ces derniers fassent l'objet d'un suivi clinique régulier, leurs connaissances sur divers aspects de la tuberculose étaient insuffisantes avant l'intervention éducative. Il faut redoubler d'efforts pour sensibiliser les patients tuberculeux à leur maladie pendant le traitement. Cette sensibilisation est importante pour aider à prévenir la maladie et à lutter contre cette dernière.

$$
\begin{aligned}
& \text { تأثير التدخل التثقيفي على الوعي بمختلف جوانب مرض السل الرئوي في المرضى المصابين به }
\end{aligned}
$$

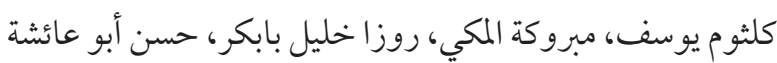

الخلفية: يمثل السل مشكلة صحية كبيرة في جميع أنحاء العالم. ويُعتبر إذكاء الوعي بمختلف جوانب مرض السل بين المصابين به أمراً مهاً للمساعدة في مكافحته و الوقاية منه.

الأهداف: هدفت هذه الدراسة شبه التجريبية، والاختبارين القبلي و البعدي إلى تقييم تأثير التدخل التثقيفي على درجة وعي المرضى المصابين بالسل الرئوي.

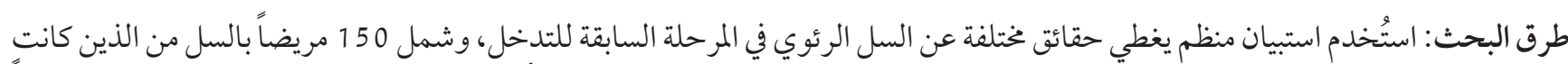

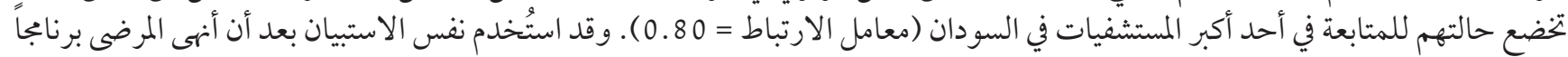
للتوعية الثقافية.

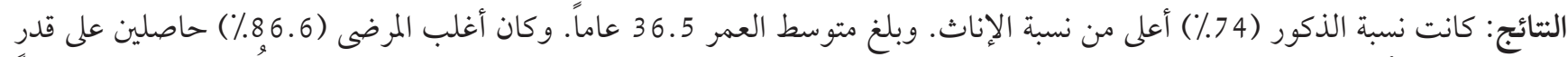

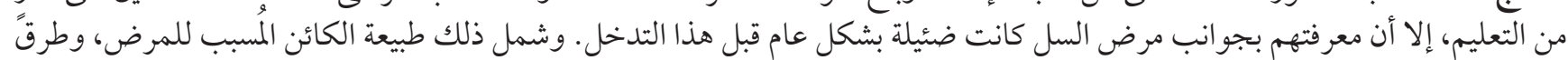

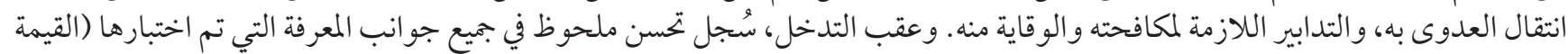
الاحتهالية > (0.0 )

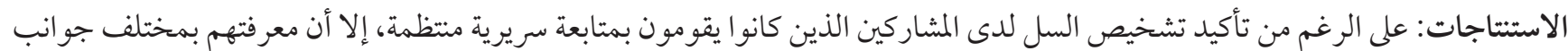

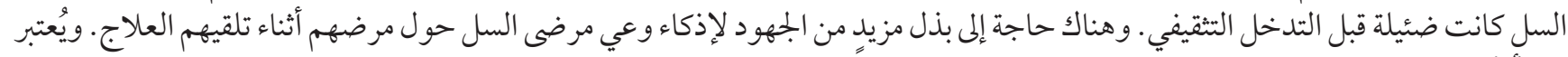

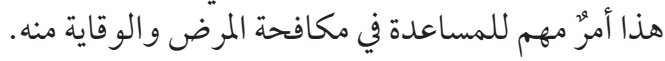




\section{References}

1. Suryakantha AH. Community medicine with recent advances, 2nd ed. New Delhi: Jaypee Brothers Medical Publishers; 2010.

2. World Health Organization global tuberculosis report. Incidence of tuberculosis (per 100 ooo people). New York: World Bank; 2015 (https://data.worldbank.org/indicator/SH.TBS.INCD, accessed 18 June 2020).

3. World Health Organization annual report 2003-2004. New Delhi: Ministry of Health and Family Welfare; 2004.

4. Alfaresi MS, Hag-Ali M. Susceptibility pattern and epidemiology of mycobacterium tuberculosis in United Emirati Hospital. Open Microbial J. 2010;4:1-4. doi:10.2174/1874285801004010001

5. Global tuberculosis report 2019. Geneva: World Health Organization; 2019 (https://apps.who.int/iris/bitstream/hand le/10665/329368/9789241565714-eng.pdf?ua=1, accessed 20 July 2020).

6. Global tuberculosis control: epidemiology, strategy, financing (WHO Report 2009); with short update. Geneva: World Health Organization; 2009 (Annex 3: The Stop TB Strategy, case reports, treatment outcomes, and estimates of TB burden) (https:// www.ghdonline.org/drtb/discussion/global-tuberculosis-control-epidemiology-strategy-/, accessed 20 July 2020).

7. Adam MA, Ali HM, Khalil EA. First-line drug resistance patterns of Mycobacterium tuberculosis complex isolates from retreatment patients from Sudan. J Tuberc Res. 2016;4:98-104. doi:10.4236/jtr.2016.43012

8. Stop TB. Geneva: World Health Organization; 2014.

9. Abdallah TM, Ali AA. Epidemiology of tuberculosis in Eastern Sudan. Asian Pac J Trop Biomed. 2012;2(12) 999-1001. doi:10.1016/ S2221-1691(13)60013-1

10. Abdallah TEM, Toum FET, Bashir OH, Mansoor TI, Yuosif MM, Elkhawad MA-E, et al. Epidemiology of extra pulmonary tuberculosis in Eastern Sudan. Asian Pac J Trop Biomed. 2015;5(6):505-8. https://doi.org/10.1016/j.apjtb.2015.02.004

11. Elsony A, Hassanain S, Aithole P. Towards a holistic perception of health: the interrelationships with identity and mobility. In: Hale S, Kadoda G, eds. Networks of knowledge production in Sudan; identities motilities and technology. New York: Rowman \& Littlefield; 2016:115-34.

12. Hassanain SA, Edwards JK, Venables E, Ali E, Adam K, Hussien H, Elsony A. Conflict and Tuberculosis in Sudan: a 10-year review of the National Tuberculosis Programme, 2004-2014. Confl Health. 2018;16;12:18. doi:10.1186/s13031-018-0154-0

13. El-Sony AI, Baraka O, Enarson DA, Bjune G. Tuberculosis control in the Sudan against seemingly insurmountable odds. Int J Tuberc Lung Dis. 2000;4(7):657-64. PMID:10907769

14. Hassan AO, Olukolade R, Ogbuji QC, Afolabi S, Okwuonye LC, Kusimo OC, et al. Knowledge about tuberculosis: a precursor to effective TB control-findings from a follow-up national KAP study on tuberculosis among Nigerians. Tuberc Res Treat. 2017;2017:6309092. doi:10.1155/2017/6309092

15. Haggag SA, Abosrea MM, Eassa S. Improving community knowledge and attitude towards pulmonary tuberculosis in Zagazig district - Sharkia governorate through application of interventional health education program. Afro-Egypt J Infect Endem Dis. 2012;2(2):77-86.

16. Global tuberculosis control, a short update to the 2009 report. Geneva: World Health Organization, 2009.

17. Park K. Parks textbook of preventive and social medicine, 19th ed. Jabalpur: Banarsidas Bhanot Publishers; 2007.

18. Manderson L, Aagaard-Hansen J, Allotey P, Gyapong M, Sommerfeld J. Social research on neglected diseases of poverty: continuing and emerging themes. PLoS Negl Trop Dis. 2009;3(2):1-10. doi:10.1371/journal.pntd.0000332

19. Lewis SL, Heltkemper MM, Dirksen SR. Medical-surgical nursing: assessment and management of clinical problems, 6th ed. St. Louis: Mosby; 2004.

20. Mondal MNI, Shitan M. Impact of socio-health factors on life expectancy in the low and lower middle income countries. Iran J Public Health. 2013;42(12):1354-62. PMID:26060637

21. Singh MM, Bano T, Pagare D, Sharma N, Devi R Mehra M. Knowledge and attitude towards tuberculosis in a slum community of Delhi. J Commun Dis. 2002;34:203-14. PMID:14703055

22. Yousif KT, Al Khayat MI, Salman HD. Survey of knowledge, attitude and practices: enhanced response to TB ACSM, Iraq. Middle East J Family Med. 2009;7(1):23-38.

23. Mushtaq UM, Shahid U, Abdullah MH, Saeed A, Fatima O F, Shad AM, et al. Urban-rural inequities in knowledge, attitudes and practices regarding tuberculosis in two districts of Pakistan's Punjab province. Int J Equity Health, 2010;10:8. doi:10.1186/14759276-10-8

24. Mondal MNI, Hoque M. Nazrul MRK, Chowdhury J, Howard: Socio-demographic factors affecting knowledge level of Tuberculosis patients in Rajshahi City, Bangladesh , Afr Health Sci. 2014 December;14(4):855-65. doi:10.4314/ahs.v14i4.13

25. The Stop TB strategy: building on and enhancing DOTS to meet the TB-related Millennium Development Goals. Geneva: World Health Organization; 2006 (WHO/HTM/TB/2006.37; https://www.who.int/tb/publications/2006/who_htm_tb_2006_368.pdf, accessed 1 July 2020).

26. Nguipdop-Djomo P, Heldal E, Rodrigues LC, Abubakar I, Mangtani P. Duration of BCG protection against tuberculosis and change in effectiveness with time since vaccination in Norway: a retrospective population-based cohort study. Lancet Infect Dis. 2016;16:219-26. doi:10.1016/S1473-3099(15)00400-4

27. Ryan KJ, Ray CG. Sherris medical microbiology, 4th ed. New York: McGraw Hill; 2014. 